\title{
Novel agents and regimens for acute myeloid leukemia: 2009 ASH annual meeting highlights
}

\author{
Xiongpeng Zhu*1,2, Yuehua Ma² and Delong Liu*2
}

\begin{abstract}
Prognostic markers, such as NPM1, Flt3-ITD, and cytogenetic abnormalities have made it possible to formulate aggressive treatment plans for unfavorable acute myeloid leukemia (AML). However, the long-term survival of AML with unfavorable factors remains unsatisfactory. The latest data indicate that the standard dose of daunorubicin (DNR) at $45 \mathrm{mg} / \mathrm{m}^{2}$ is inferior to high dose $90 \mathrm{mg} / \mathrm{m}^{2}$ for induction therapy. The rates of complete remission and overall survival are significantly better in the high dose induction regimen. New regimens exploring the new liposomal encapsulation of Ara-C and DNR as well as addition of gemtuzumab ozogamicin monoclonal antibody have been studied. New agents, including the nucleoside analogues (clofarabine, sapacitabine, elacytarabine), FLT3 inhibitor (sorafenib), farnesyl-transferase inhibitor (tipifarnib), histone deacetylase inhibitor (vorinostat), lenalidomide, as well as DNA methyltransferase inhibitors (decitabine, azacitidine), were recently reported for AML treatment in the 2009 ASH annual meeting. This review also summarizes the updates of the clinical trials on novel agents including voreloxin, AS1413, behenoylara-C, ARRY520, ribavirin, AZD1152, AZD6244, and terameprocol (EM-1421) from the 2009 ASH annual meeting.
\end{abstract}

\section{Introduction}

Acute myeloid leukemia (AML) is the most common type of acute leukemia in adults. Over the past twenty years, the studies on the pathogenesis and prognosis of AML have made revolutionary progress. However, only onethird of adult AML can be cured even to this date. The treatment of refractory, relapsed and elderly AML remains a major challenge. In recent years, new regimens and novel agents are being studied in an effort to improve complete remission (CR) rate and overall survival. This study will review the latest advances in AML treatment and summarize the highlights from the 2009 ASH Annual Meeting.

\section{New regimens for induction therapy of newly diagnosed AML \\ High dose daunorubicin improves survival}

The standard induction regimen for newly diagnosed AML consists of daunorubicin (DNR) $45 \mathrm{mg} / \mathrm{m}^{2}$ intrave-

*Correspondence: xiongpengzhu@163.com, delong_liu@nymc.edu 1 Department of Hematology, First Hospital of Quanzhou Affiliated to Fujian Medical University, Quanzhou, 362000, China

Full list of author information is available at the end of the article nously for 3 days and cytarabine (AraC) $100 \mathrm{mg} / \mathrm{m}^{2}$ by continuous infusion for 7 days [1]. With this regimen $60 \%$ to $80 \%$ of young adults and $40 \%$ to $60 \%$ of older adults can achieve a CR.

Several major studies, particularly Cancer and Leukemia Group B (CALGB) $9621[2,3]$ and the French ALFA 9000 studies [4], have shown that higher doses of DNR $\left(80\right.$ or $90 \mathrm{mg} / \mathrm{m}^{2}$ ) can be administered safely. Recently, there are two major prospective studies compared DNR $90 \mathrm{mg} / \mathrm{m}^{2}$ with $45 \mathrm{mg} / \mathrm{m}^{2}$ in the induction regimen. Eastern Cooperative Oncology Group (ECOG) studied 657 AML patients between the age of 17 to 60 [5]. The study showed significantly higher CR rate for patients receiving $90 \mathrm{mg} / \mathrm{m}^{2}$ (70\% versus 57\%). More importantly, overall survival (OS) was significantly prolonged (23.7 vs 15.7 months). The Dutch-Belgium Hemato-Oncology Cooperative Group (HOVON)/Swiss Group for Clinical Cancer Research (SAKK) compared DNR $90 \mathrm{mg} / \mathrm{m}^{2}$ versus 45 $\mathrm{mg} / \mathrm{m}^{2}$ in 813 patients older than 60 years [6]. The results showed that CR rate was $64 \%$ and $54 \%$ respectively, while $\mathrm{CR}$ rate after only one course of treatment was $52 \%$ and $35 \%$ respectively. The OS rate was not significantly different for the whole group. However, for the patients 
between the age of 60 to 65 , the OS rate was significantly better in the high dose group (38\% vs $23 \%$ ). The rates of serious adverse events were similar in the two treatment groups in both studies.

Based on historic trials and the most recent prospective studies, Rowe points out that $45 \mathrm{mg} / \mathrm{m}^{2}$ of DNR should no longer be the standard-dose for induction therapy [7]. Instead, for induction therapy of all age groups, DNR dose should be between $60 \mathrm{mg} / \mathrm{m}^{2}$ to $90 \mathrm{mg} / \mathrm{m}^{2}$ for 3 days, but the exact optimal dosage remains to be established.

\section{New formulations of old agents}

Liposomal encapsulation of drugs can reduce the toxicity and decrease drug doses with controlled-release effect. CPX-351 is a liposomal formulation that encapsulates cytarabine and daunorubicin at a 5:1 molar ratio. A recently completed phase 1 study recommended that 90minute infusions of $101 \mathrm{u} / \mathrm{m}^{2}$ be given on days 1,3 , and 5 $(1 \mathrm{u}=1 \mathrm{mg}$ Ara-C $+0.44 \mathrm{mg}$ DNR) [8]. The results showed that liposomal encapsulation of this chemotherapy doublet changed the safety profile by reducing nonhematologic toxicities including hair loss, gastrointestinal toxicities and hepatic toxicity, while retaining hematopoietic cytotoxicity. A phase IIb randomized study was initiated to compare CPX-351 with conventional DA regimen (Ara-C + DNR) in AML patients aged 60-75. CPX-351 exhibits an acceptable safety profile for use in older, newly diagnosed AML patients[9].

\section{Targeted therapy regimens}

In recent years, encouraging results have been achieved by using monoclonal antibodies for targeted therapy of the solid and hematologic malignancies. CD33 antigen is expressed in more than $90 \%$ of AML cells, while expression in normal tissue is very weak. Gemtuzumab ozogamycin (GO) is chemoimmunotherapy agent consisting of a monoclonal antibody against CD33 conjugated to calichemycin. GO triggers apoptosis when hydrolyzed in the leukemic blasts. GO has been approved by the U.S. FDA for the treatment of the elderly (> 60 years) with AML in first relapse [10]. Standard induction regimen with or with out GO were compared in a randomized study which enrolled 1115 younger adults with AML. The results showed a similar CR rate in both arms, but a significantly improved DFS among patients receiving GO-$51 \%$ versus $40 \%$ at 3 years $(P=.008)[11]$.

$\mathrm{GO}+$ chemotherapy is also used in AML with special chromosome abnormalities. GO + FLAG has been used to treat 34 cases of newly diagnosed AML younger than 60 with core binding factor $(\mathrm{CBF})$ abnormality $[\operatorname{Inv}(16)=$ $10 ; t(8 ; 21)=24]$. The induction regimen consisted of the following agents: Fludarabine $30 \mathrm{mg} / \mathrm{m}^{2} / \mathrm{d}, \mathrm{d} 1-5$, Ara-C 2 $\mathrm{g} / \mathrm{m}^{2} / \mathrm{d}, \mathrm{d} 1-5$, GO $3 \mathrm{mg} / \mathrm{m}^{2} / \mathrm{d} 1$, and G-CSF $3 \mathrm{mg} / \mathrm{kg} / \mathrm{d}$. The GO-FLAG regimen in $\mathrm{CBF}^{+} \mathrm{AML}$ yielded impressive clinical and molecular response in 29 of the 34 patients[12].

A phase II study of My-FLAI aiming to assess toxicity and efficacy was done in patients with newly diagnosed AML aged more than 60 years. Fifty-one patients were enrolled with a median age of 68 years. Twenty-five patients had a secondary AML and $31 \%$ had a complex karyotype. Fludarabine $\left(25 \mathrm{mg} / \mathrm{m}^{2}\right)$, cytarabine $\left(1 \mathrm{~g} / \mathrm{m}^{2}\right)$, and idarubicin $\left(5 \mathrm{mg} / \mathrm{m}^{2}\right)$ were administered for three consecutive days. GO (5 mg) was infused at day four. Twenty-seven patients achieved a CR and 4 obtained a partial response for an overall response rate (ORR) of $61 \%$. The results showed that the four drug regimen MyFLAI was well tolerated in an elderly AML population, but its efficacy did not appear to be superior to that of standard "3+7" regimen[13].

\section{New regimens for refractory/relapsed AML}

High-dose cytarabine (HiDAC) is commonly used for induction of relapsed or refractory AML. At the 2009 ASH meeting, Sarah et al reported a novel, timedsequential regimen that takes advantage of synergy when mitoxantrone is given after cytarabine [14]. It was a retrospective analysis of patients with relapsed or refractory high-risk AML. Those patients received HiDAC/mitoxantrone regimen, with cytarabine at $3 \mathrm{gm} / \mathrm{m}^{2}$ over four hours on days 1 and 5 plus mitoxantrone at $30 \mathrm{mg} / \mathrm{m}^{2}$ over one hour immediately following the HiDAC on days 1 and 5 . HiDAC/mitoxantrone induction was well tolerated and demonstrated an overall response rate of $55 \%$ with induction death rate of $9 \%$.

To further enhance the CR rate in refractory/relapsed AML, the Japanese Adult Leukemia Study Group (JALSG) reported a phase II study of FLAGM (Fludarabine + High-Dose Ara-C + G-CSF + mitoxantrone) in 41 patients with relapsed or refractory AML. The patients were treated with fludarabine $15 \mathrm{mg} / \mathrm{m}^{2}$ twice daily (d14), Ara-C $2 \mathrm{~g} / \mathrm{m}^{2}$ (d1-4), G-CSF $300 \mu \mathrm{g} / \mathrm{m}^{2}$ (d1-4), and mitoxantrone $10 \mathrm{mg} / \mathrm{m}^{2}(\mathrm{~d} 3-5)$. FLAGM yielded a $70 \%$ response rate in either relapsed or refractory AML patients. Although randomized studies are still needed, FLAGM appears to be a good option for the treatment of either relapsed or refractory AML patients [15].

Thomas et al conducted a retrospective analysis of response (CR and $\mathrm{CRi}$ ) and survival for patients with first relapsed AML treated with either IHDAraC or IHDAraC $+\mathrm{GO}$ regimen [16]. Univariate analysis showed that IHDAraC + GO induction, as compared with IHDAraC, was associated with a better response rate $(68 \%$ vs $48 \%$, $p$ $=0.08)$, a lower relapse rate $(31 \%$ vs $66 \%, p=0.02)$, a better overall survival (median 35 months vs 19 months, $\mathrm{p}=$ 0.02 ) and a better event free survival (median not reached vs 10 months, $\mathrm{p}=0.02$ ). 


\section{New Agents}

\section{Nucleoside analogues}

Nucleoside analogues transform into active metabolites (triphosphate nucleoside analogues) in the cells and inhibit DNA synthesis. Clofarabine is a new nucleoside analogue, a potent inhibitor of both ribonucleotide reductase and DNA polymerase. At the 2009 ASH meeting, a few studies on clofarabine were reported, either clofarabine alone or in combination with low-dose Ara$\mathrm{C}$, or high-dose Ara-C with the monoclonal antibody GO in the treatment of elderly AML or relapsed AML [1721]. Two novel nucleoside analogues, sapacitabine and elacytarabine, were also reported for the therapy of the elderly with refractory or relapsed AML $[22,23]$ (Table 1).

In a preliminary study, twenty patients with relapsed/ refractory AML were enrolled to receive a regimen including intermediate dose Ara-C, clofarabine and GO [17]. The preliminary results was 10 of $20(50 \%)$ patients achieved a complete remission, $1 / 20$ a partial response, $7 /$ 20 had resistant disease, $2 / 20$ died of complications during the aplastic phase. Further studies are warranted (Table 1).

In a single-arm, multi-center, phase II, open-label trial, 112 patients of previously untreated AML, $\geq 60$ years old, and with at least one unfavorable prognostic factor were enrolled to receive single agent clofarabine [18]. In patients $\geq 70$ y $(\mathrm{n}=69)$, ORR was $39 \%$, CR 33\%; In patients with unfavorable cytogenetics $(n=62)$, ORR was $42 \%$, CR $32 \%$. Patients with 2 unfavorable prognostic factors $(n=45)$ had ORR of $51 \%$. Patients with 3 unfavorable factors $(n=40)$ had ORR $38 \%$. Patients $\geq 70$ with intermediate or unfavorable karyotype $(n=25)$ had ORR $48 \%$ and CR 40\%; in patients $\geq 70$ with unfavorable karyotype $(\mathrm{n}=9)$ ORR and CR were $56 \%$. Patients $\geq 70$ with both AHD and unfavorable karyotype ( $\mathrm{n}=18)$, ORR was $33 \%$ and CR $22 \%$. In patients $\geq 70$ with AHD and intermediate karyotype $(n=8)$, ORR and CR were $63 \%$ (Table 1$)$. It therefore appears that single agent clofarabine has reasonable activity in newly diagnosed elderly AML patients.

There was another report of a phase II trial which enrolled 38 patients with relapsed or refractory AML. The patients received a regimen with G-CSF priming, clofarabine and high dose Ara-C (GCLAC) [19]. The CR was $45 \%$ and the $C R+C R p$ rate was $64 \%$. These rates were $50 \% \mathrm{CR}$ and $65 \% \mathrm{CR}+\mathrm{CRp}$ among $1^{\text {st }}$ salvage patients (95\% CI 41-85\%), respectively, and 70\% CR + CRp excluding patients who relapsed after allogeneic SCT (Table 1). It is important to point out that the relatively higher $C R$ rate could be in part due to the higher dose of AraC.

Clofarabine was tested in a phase I, dose escalation study in fourteen patients with relapsed and refractory AML, who received clofarabine in combination with fractionated GO in 2 cohorts. The MTD of clofarabine in combination with fractionated GO is $20 \mathrm{mg} / \mathrm{m}^{2} /$ day for 5 days [20] (Table 1).

Forty patients with AML were enrolled in a phase II study to receive clofarabine plus low-dose Ara-C induction followed by consolidation with clofarabine plus lowdose Ara-C alternating with decitabine. Of the 34 patients evaluable for response, $20(59 \%)$ achieved $C R$ and 2 (6\%) CRp for an overall response rate (ORR) of $65 \%$. The therapy achieves high response rate with a manageable toxicity profile and low induction mortality in elderly patients with previously untreated AML [21](Table 1).

Table 1: Nucleoside analogues in clinical trials

\begin{tabular}{|c|c|c|c|c|c|c|c|}
\hline Study Agents & Other agents & Disease & Dosage & $\begin{array}{l}\text { Clinical } \\
\text { trails }\end{array}$ & No Pts & Response & Reference \\
\hline Clofarabine & HD Cytarabine, & $\begin{array}{l}\text { Relapsed and } \\
\text { refractory } \mathrm{AML}\end{array}$ & $\begin{array}{l}22,5 \mathrm{mg} / \mathrm{m}^{2} \text { i.v qd, d1-5 } \\
\mathrm{GO} 6 \mathrm{mg} / \mathrm{m}^{2} \mathrm{~d} 6\end{array}$ & Phase II & 20 & CR 50\% & {$[17]$} \\
\hline Clofarabine & & Elderly AML & $\begin{array}{l}20-30 \mathrm{mg} / \mathrm{m}^{2} \\
\text { i.v qd, d1-5 }\end{array}$ & Phase II & 112 & CR $33-56 \%$ & {$[18]$} \\
\hline Clofarabine & HD Cytarabine & $\begin{array}{l}\text { Relapsed and } \\
\text { refractory } \mathrm{AML}\end{array}$ & $25 \mathrm{mg} / \mathrm{m}^{2} / \mathrm{d} 1-5 \mathrm{~d}$ & Phase III & 38 & CR $45 \%$ & {$[19]$} \\
\hline Clofarabine & GO & $\begin{array}{l}\text { Relapsed and } \\
\text { refractory } \mathrm{AML}\end{array}$ & $20 \mathrm{mg} / \mathrm{m}^{2} / \mathrm{d}$ or $30 \mathrm{mg} / \mathrm{m}^{2} / \mathrm{d} \mathrm{d} 1-5$ & Phase I & 14 & $\begin{array}{l}\text { MTD: } 20 \mathrm{mg} / \mathrm{m}^{2} \\
\text { clofarabine }\end{array}$ & {$[20]$} \\
\hline Clofarabine & LD Cytarabine & $\begin{array}{l}\text { Elderly untreated } \\
\text { AML }\end{array}$ & $20 \mathrm{mg} / \mathrm{m}^{2}$ i.v qd, d1-5 & Phase II & 40 & $\begin{array}{l}\text { CR 59\% } \\
\text { CRp 6\% }\end{array}$ & {$[21]$} \\
\hline Sapacitabine & & $\begin{array}{l}\text { Elderly Relapsed } \\
\text { and refractory AML }\end{array}$ & $\begin{array}{l}200 \text { or } 300 \mathrm{mg} \text { po bid } \times 7 \mathrm{~d}, 400 \mathrm{mg} \\
\text { po bid } \times 3 \mathrm{~d} / \mathrm{w} \times 2 \mathrm{w}\end{array}$ & Phase II & 60 & CR $10 \%$ & {$[22]$} \\
\hline Elacytarabine & & $\begin{array}{l}\text { Relapsed and } \\
\text { refractory } \mathrm{AML}\end{array}$ & $2,000 \mathrm{mg} / \mathrm{m} 2$ CIV d1-5q3w & Phase II & 61 & CR 15\% & {$[23]$} \\
\hline
\end{tabular}

Abbreviations: GO: gemtuzumab ozogamycin; HD: high dose; LD, low dose; CRp: CR without platelet recovery; MTD: maximal tolerated dose; 


\section{FLT3 inhibitors (Fms-like tyrosine kinase 3 inhibitors)}

The Flt3-internal tandem duplication (ITD) can be found in approximately $30 \%$ of all AML patients and confers a poor risk status characterized by an increased relapse rate and poor overall survival [24]. Moreover, Flt3-ITD-positive AML patients relapsing after allogeneic stem cell transplantation (SCT) have very limited therapeutic options. Sorafenib is a multikinase inhibitor that is approved for the treatment of metastatic renal cell and hepatocellular carcinoma. A questionnaire was developed and sent to 28 centers in Germany in order to obtain more insight into the clinical efficacy and tolerability of sorafenib monotherapy in Flt3-ITD positive AML. Of the 18 patients treated with sorafenib, five were primary refractory to induction chemotherapy and 13 were in first $(\mathrm{n}=11)$ or second $(\mathrm{n}=2)$ relapse. Patients received between $200 \mathrm{mg}$ and $800 \mathrm{mg}$ sorafenib p.o. daily. The median treatment duration was 98 days (range, 16425 days). All patients achieved a hematological response $(\mathrm{HR})$ characterized by complete $(\mathrm{n}=16)$ or near complete peripheral blast clearance $(\mathrm{n}=2)$. After a median treatment duration of 180 days (range, 82-270 days), 7 of 18 (39\%) patients developed clinical resistance. Therefore, sorafenib monotherapy has significant clinical activity in Flt3-ITD positive relapsed and refractory AML [25].

In addition, combination therapy with sorafenib was shown to be effective in reducing mutant clones in patients with FLT3 mutations but was not able to completely eradicate them. These data suggest that sorafenib can achieve temporary disease control, but should be integrated into induction and consolidation regimens to achieve maximal outcome [26-28] (Table 2).

Another retrospective study analyzed sorafenib treatment in 128 patients [26]. Among these patients, twentythree patients (18 FLT3-WT, 5 FLT3 mutated) received
FLT3 inhibitors as part of their induction and 9 of them achieved either CR $(n=6)$ or CRp $(n=3)$. These results suggest that therapy with FLT3 inhibitors has the potential to improve the outcome of patients with FLT3 mutations (Table 2). Prospective study is needed to confirm the findings.

In another clinical study, sorafenib was evaluated in 8 AML patients with FLT3+ either prior to or after allogeneic stem cell transplantation (allo-SCT) [27]. Two of four patients who received sorafenib for refractory/ relapsed AML after allo-SCT achieved complete remission (CR), the other two pts had hematological response. The rest four patients were treated prior to allo-SCT. Two of the four relapsed patients showed response to sorafenib treatment, thereby permitting allo-SCT. One of these two patients achieved HR, the other had regression of multiple isolated cutaneous manifestations. Sorafenib treatment was well tolerated (Table 2).

In a phase II study, eighteen patients with newly diagnosed AML and mutated FLT3 were enrolled to receive sorafenib, idarubicin, and Ara-C [28]. 94\% of the patients achieved a morphological CR/CRp and 6\% achieved PR. This regimen was found to be effective in reducing the mutant clones (Table 2).

In summary, sorafenib appears to provide a useful option for treatment of relapsed/refractory AML patients. However, large prospective study is needed to confirm the results from the small observational studies.

\section{Farnesyl-transferase inhibitor (FTI)}

In recent years, studies have shown that Ras gene mutation plays an important role in leukemogenesis [29]. By inhibiting farnesyl protein transferase, FTI prohibits the Ras protein farnesylation, schizolysis and carboxyl methylation, thus disrupting the critical Ras signaling pathway.

Table 2: FLT3 inhibitors in clinical trials

\begin{tabular}{|c|c|c|c|c|c|c|c|}
\hline $\begin{array}{l}\text { Study } \\
\text { Agents }\end{array}$ & Other agents & Disease & Dosage & Clinical trails & No Pts & Response & Reference \\
\hline Sorafenib & & $\begin{array}{l}\text { Flt3-ITD+ } \\
\text { Relapsed and } \\
\text { refractory AML }\end{array}$ & $\begin{array}{l}200 \mathrm{mg}-800 \\
\mathrm{mg} \mathrm{qd}\end{array}$ & retrospective & 26 & CHR: $88 \%$ & [25] \\
\hline Sorafenib & $\begin{array}{l}\text { as part of } \\
\text { induction } \\
\text { therapy and } \\
\text { salvage }\end{array}$ & $\begin{array}{l}\text { FLT3+AML, } \\
\text { untreated } \\
\text { Relapsed }\end{array}$ & & retrospective & 128 & CR/CRp: 7\% & [26] \\
\hline Sorafenib & & $\begin{array}{l}\text { FLT3+AML } \\
\text { Relapsed and } \\
\text { refractory }\end{array}$ & $800 \mathrm{mg}$ q.d & retrospective & 8 & CR: $25 \%$ & {$[27]$} \\
\hline Sorafenib & $\begin{array}{l}\text { Idarubicin, } \\
\text { cytarabine }\end{array}$ & $\begin{array}{l}\mathrm{FLT3}^{+} \mathrm{AML} \\
\text { untreated }\end{array}$ & $\begin{array}{l}400 \mathrm{mg} \text { po } \\
\text { bid } \times 7 \mathrm{~d}\end{array}$ & Phase II & 18 & $\begin{array}{l}\text { CR/CRp: } \\
94 \%\end{array}$ & [28] \\
\hline
\end{tabular}

Abbreviations: CR: complete remission; CRp: CR without platelet recovery; CHR: complete hematological response 
A phase II study assessed the efficacy and toxicity of tipifarnib-bortezomib combination in 80 AML patients $>18$ years, unfit for conventional therapy, or $>60$ years, in relapse (Table 3$)$. Nine patients $(11 \%)$ achieved CR, 1 patient had PR, and in 2 cases an hematological improvement (HI) was documented for an overall response rate (ORR) of $19 \%$. Tipifarnib ( \pm bortezomib) may represent an important option in a subset of high risk/frail AML patients [30].

Feldman et al compared efficacy of tipifarnib +/- oral etoposide with traditional cytarabine/anthracyclinebased induction regimen in older patients with AML. The results suggest that better CR did not translate into better survival outcomes (median OS 6.2 vs 7.7 months; $p$ $=0.82$ by log-rank test) [31].

\section{Histone deacetylase inhibitors}

Vorinostat is a new anti-cancer agent inhibiting histone deacetylase and has been shown to have some efficacy in treatment of AML [32-34]. Vorinostat in combination with idarubicin and ara-C has synergistic antileukemia activity in a sequence dependent fashion $[35,36]$. A phase II study of vorinostat in combination with idarubicin and cytarabine as front line therapy for AML or MDS patients was reported (Table 4). This study enrolled 52 pts at the time of the report, and 45, all with AML, are evaluable for response (median age 53 yeas (range 19-65). The CR after one course of therapy was achieved in $35 \mathrm{pts}$ and $1 \mathrm{pt}$ achieved a CRp with incomplete platelet recovery for an overall response rate of $80 \%$. Seven (15\%) pts did not respond to therapy. Therefore, the combination of vorinostat, idarubicin and cytarabine is safe and active in AML[37]. CR or CRi was achieved by $18 \%$ pts with MDS, $8 \%$ with relapsed/refractory AML, and 36\% with untreated AML; and HI was reported in $9 \%$ pts with MDS, $4 \%$ with relapsed/refractory AML, and $8 \%$ with untreated AML.

There was also a preliminary report of a Phase I, openlabel, multicenter, dose-escalating study, designed to determine the maximum-tolerated dose (MTD) vorinostat combined either concurrently or sequentially with decitabine in patients (pts) with AML/MDS. 72 patients were enrolled. CR or CRi (CR with incomplete count recovery) was achieved by $18 \%$ pts with MDS, $8 \%$ with relapsed/refractory AML, and 36\% with untreated AML. Thus, the combination of vorinostat with decitabine, either concurrently or sequentially, is possible without significant toxicity, and shows activity in MDS and untreated AML[38].

\section{DNA Methyltransferase inhibitors}

Decitabine inhibits DNA methyltransferase, leading to DNA hypomethylation and cell differentiation or apoptosis. A combination of decitabine and GO was found to be effective with low side effects in previously untreated or refractory/relapsed AML patients, especially in elderly patients[39]. In this phase II study, 33 previously untreated patients with AML/high-Risk MDS were enrolled to received GO with decitabine. $24 \%$ of the patients had CR/CRp. Five (15\%) patients had clearance of marrow blasts and 1 patient had hematological improvement (hemoglobin). The toxicities were minimal and the regimen can be safely delivered to older patients (Table 5). In a retrospective study, 79 patients with relapsed or refractory AML received decitabine/GO combination. $34 \%$ patients responded: $16 \%$ CR; $5 \%$ CRp; $13 \%$ PR-[40]. It is noteworthy that the response rates from these two studies are similar to that of the single agent GO, and therefore could be mainly due to the activity of GO (Table 5)

The French ATU program performed a retrospective analysis of 184 patients with refractory or relapsed AML who received azacytidine [41]. $11 \%$ of the patients responded $(7 \% \mathrm{CR}, 3 \% \mathrm{CRi}, 1 \% \mathrm{PR})$. It appears that single agent azacytidine has only limited activity in AML patients relapsed or refractory to intensive frontline therapy (Table 5).

Combination of azacitidine with bortezomib or lowdose GO was also studied in relapsed or refractory AML patients [41-43] (Table 5).

In a retrospective analysis, 56 patients with poor-risk AML/MDS received treatment with azacitadine and lowdose GO. $27 \%$ of the patients achieved a CR/CRi. An additional seven patients cleared their peripheral blood blasts or had hematologic improvement but did not have remission [42] (Table 5).

In a phase I study, 23 patients with relapsed or refractory AML were enrolled to receive bortezomib and 5azacytidine. The response rate was 26\% (6/23) (3-CR, 2$\mathrm{CRi}$, and 1-PR). The combination of 5-azacytidine and bortezomib was well tolerated and appeared to be active in this cohort of relapsed or refractory AML patients [43] (Table 5).

In a phase I dose-finding trial, twenty eight patients with AML/MDS were enrolled to receive vorinostat plus azacitidine (AZA) in 8 cohorts [44]. Surprisingly, 53\% of the patients achieved CR. In particular, 10 of 12 high-risk MDS/AML patients (83\%) went into CR. This combination was found to be well tolerated in repetitive cycles. The optimal dose of AZA in this regimen appears to be $55 \mathrm{mg} / \mathrm{m}^{2}$. Phase II study is being done.

\section{Novel agents in early clinical development Voreloxin}

Voreloxin is a first-in-class anticancer quinolone derivative that intercalates DNA, inhibits topoisomerase II, and induces apoptosis. A preliminary report on a voreloxin trial revealed clinical activity in previously untreated 
elderly (age $\geq 60$ ) AML patients who are unlikely to benefit from standard chemotherapy[45]. In this phase II dose optimization study, 105 patients were treated, with 93 patients evaluable. The CR + CRp rate of the 3 dose schedules was $41 \%, 29 \%, 38 \%$, respectively. ORR across the 3 schedules was 35\%; (Table 6). The study is still ongoing.

\section{Amonafide L-malate (AS1413)}

Amonafide L-malate (amonafide, AS1413) is a unique DNA intercalator. In a phase II study, 88 patients with secondary AML were enrolled to receive amonafide and Ara-C. Overall CR + CRi rate was $42 \%$. CR rates among age $<60$ and $\geq 60$, was $39.4 \%$ and $43.6 \%$, respectively; among tAML and prior MDS, $40 \%$ and $44.2 \%$, respectively; for patients with intermediate and unfavorable cytogenetics, the CR rates were $61.1 \%$ and $23.8 \%$, respectively (Table 6). This study showed that amonafide in combination with cytarabine produced a high complete remission rate and durable responses in both older and younger patients with secondary AML[46]

\section{Behenoylara-C}

Behenoylara-C has three-phosphoryl in the fourth $\mathrm{N}$ of Ara-C, making it more lipophilic than Ara-C. Its concentration is maintained longer in the blood (especially blood cells) and tissues. This agent is transformed into Ara-C in the liver, spleen, kidney and leukemia cells, which inhibits DNA synthesis. Taiichi et al studied 165 patients with untreated AML using the combination of behenoylara- $\mathrm{C}$ and idarubicin. $86.7 \%$ of the patients had $\mathrm{CR}$. The patients with good or intermediate risk factors had remarkable improvements. The study showed that the treatment is effective and safe [47] (Table 6).

\section{Lenalidomide}

Lenalidomide is one of the three new drugs approved by the U.S. FDA to treat MDS $[48,49]$. Treatment of 5q-lowrisk MDS with LEN can achieve high rate of cytogenetic CR. In a recent phase II study of LEN in combination with Ara-C and daunorubicin in high risk MDS/AML with del 5q, 28\% responded (Table 6). The results show that LEN combined with chemotherapy in AML treatment is feasible, without significant additional toxicity[50].

\section{Table 3: Farnesyl-transferase inhibitor in clinical trials}

\begin{tabular}{|c|c|c|c|c|c|c|c|}
\hline inhibitors & $\begin{array}{l}\text { Other } \\
\text { agents }\end{array}$ & Disease & Dosage & $\begin{array}{l}\text { Clinical } \\
\text { trails }\end{array}$ & No Pts & Response & Reference \\
\hline Tipifarnib & $\begin{array}{l}\text { Bortezomib } \\
1.0 \mathrm{mg} / \mathrm{m}^{2}\end{array}$ & $\begin{array}{l}\text { Elderly or } \\
\text { relapsed } \\
\text { AML }\end{array}$ & $\begin{array}{l}300-600 \mathrm{mg} \\
\mathrm{bid}, \times 21 \mathrm{~d}\end{array}$ & Phase II & 80 & CR: $11 \%$ & [30] \\
\hline Tipifarnib & $\begin{array}{l}+/- \\
\text { etoposide }\end{array}$ & $\begin{array}{l}\text { Elderly } \\
\text { untreated } \\
\text { AML }\end{array}$ & & Phase II & 107 & Safe & [31] \\
\hline
\end{tabular}

\section{Ribavirin}

The eukaryotic translation factor, eIF4E, is overexpressed in AML, and is associated with poor prognosis. Ribavirin is clinically used as an antiviral molecule, and its structure is similar to the $\mathrm{m}(7) \mathrm{G}$ cap of mRNA, thus inhibiting eIF4E-induced export and translation of sensitive transcripts. Assouline et al carried out the first clinical trial targeting eIF4E with ribavirin in combination with $\mathrm{AraC}$ in AML patients (Table 6). Clinical and molecular efficacy has been evaluated in 13 patients. The treatment was well tolerated by all patients. No hemolytic anemia was seen. There was one complete remission, two partial remissions, two blast responses and four patients with stable disease. Unfortunately, all patients eventually acquired resistance to therapy and eventually relapsed. Hence, the novel therapies combined with ribavirin are being sought to overcome resistance and prolong remission[51].

ARRY-520

The kinesin spindle protein (KSP) plays a major role for the assembly of a normal bipolar spindle and is also required for cell cycle progression through mitosis. ARRY-520 is a potent, selective inhibitor of KSP. Thirtythree patients with AML were enrolled to receive different schedule of ARRY-520: 15 in the single-dose schedule (dose levels 2.5, 3.75, 4.5 and $5.6 \mathrm{mg} / \mathrm{m}^{2}$ ) and 18 in the divided dose schedule (dose levels $0.8,1.2,1.5$ and 1.8 $\mathrm{mg} / \mathrm{m}^{2} /$ day). The maximal tolerated dose (MTD) was 4.5 $\mathrm{mg} / \mathrm{m}^{2}$ for the single-dose schedule with the dose-limiting toxicity (DLT) of grade 3 mucositis. The MTD was 1.5 $\mathrm{mg} / \mathrm{m}^{2} /$ day (cumulative dose per cycle of $4.5 \mathrm{mg} / \mathrm{m}^{2}$ ) for the divided dose schedule, with DLTs being grade 3 mucositis, hand-foot syndrome and hyperbilirubinemia. ARRY-520 was well tolerated. Four of 33 patients (12\%) showed at least $50 \%$ reduction in bone marrow blasts (Table 6). Therefore, ARRY-520 showed promising clinical activity and was well tolerated in both schedules[52].

AZD1152

Aurora B kinase plays a major role in regulating mitosis and is overexpressed in AML. AZD1152 is a highly potent and selective inhibitor of aurora B kinase. It has been shown to inhibit tumor growth in vivo. A phase I/II study was conducted to assess the safety and efficacy of 
Table 4: Histone deacetylase inhibitors in clinical trials

\begin{tabular}{|c|c|c|c|c|c|c|c|}
\hline $\begin{array}{l}\text { Study } \\
\text { Agents }\end{array}$ & $\begin{array}{l}\text { Other } \\
\text { agents }\end{array}$ & Disease & Dosage & $\begin{array}{l}\text { Clinical } \\
\text { trails }\end{array}$ & No Pts & Response & Reference \\
\hline Vorinostat & $\begin{array}{l}\text { Idarubicin, } \\
\text { Cytarabine }\end{array}$ & $\begin{array}{l}\text { untreated } \\
\text { AML }\end{array}$ & $\begin{array}{l}500 \mathrm{mg} \text { po } \\
\text { tid d } 1-3\end{array}$ & Phase II & 52 & $\begin{array}{l}\text { CR/CRp: } \\
80 \%\end{array}$ & [37] \\
\hline Vorinostat & decitabine & $\begin{array}{l}\text { untreated, } \\
\text { relapsed } \\
\text { AML }\end{array}$ & $\begin{array}{l}400 \mathrm{mg} \text { qd, } \\
\text { po } 1-7 \mathrm{~d} \text { or } \\
1-14 \mathrm{~d}\end{array}$ & Phase I/II & 72 & $\begin{array}{l}\text { MTD not } \\
\text { reached }\end{array}$ & [38] \\
\hline
\end{tabular}

Abbreviations: CR: complete remission; CRp: CR without platelet recovery; MTD: maximal tolerated dose;

AZD1152 in patients aged $>18$ years with advanced AML (Table 6). The MTD of AZD1152 was defined as $1200 \mathrm{mg}$ in patients with relapsed AML, and an overall clinical response rate $(\mathrm{CR}+\mathrm{CR} \mathrm{i}+\mathrm{PR})$ of $23 \%$ was observed [53].

\section{AZD6244}

AZD6244 is one of the orally bioavailable small molecule inhibitors of MEK kinase [54,55]. AZD6244 was studied in 47 relapsed or refractory AML in a phase II multicenter clinical study [56]. Among these patients, FLT3 ITD or TKD mutation was positive in 10, negative in 36, mutational status was unknown in 1. Median number of prior therapies for AML and/or MDS was 2 (range, 0-6). The AZD6244 dose was $100 \mathrm{mg}$ twice daily; 42 pts were evaluable. Median number of cycles administered was 1 (range, 1-9). AZD6244 related serious adverse events included fatigue, nausea and dehydration, occurring in $7 \%, 5 \%$ and $5 \%$, respectively. Minor responses were seen, no CR was reported. The study showed that the oral MEK inhibitor AZD6244 is tolerable in AML. Further investigation of AZD6244 in combination with drugs that target other critical signaling/transcriptional pathways in AML is being considered.

\section{Terameprocol}

The inhibitor of apoptosis protein (IAP), survivin, is a key regulator of cell cycles. In leukemic cells, survivin is involved in leukemia cell survival and resistance to che- motherapeutics and Flt-3 inhibitors. A clinical trial with terameprocol (EM-1421), a novel survivin and cdc2 (CDK1) inhibitor, was done in patients with advanced hematological malignancies (Table 6). In a phase I dosefinding trial, 16 patients with advanced, relapsed or refractory hematological malignancies were treated with 1000,1500 or $2200 \mathrm{mg}$ of intravenous terameprocol $3 \times /$ week (wk) for 2 of $3 \mathrm{wks}$. The MTD was found to be 1500 $\mathrm{mg} 3 \times /$ week for 2 of 3 wks [57].

\section{Conclusions and future directions}

Prognostic markers, such as NPM1, Flt3-ITD, and cytogenetic abnormalities have made it possible to prospectively formulate aggressive treatment plans for unfavorable AML. However, the long-term survival of AML with unfavorable factors remains unsatisfactory. Combination of azacytidine and vorinostat showed surprisingly high response rate. Prolonged survival without curing high risk MDS/AML patients with azacytidine therapy suggests that disease modification instead of cure of AML patients may be an alternative goal of treating elderly patients not suitable for aggressive therapy. New regimens and novel agents targeting specific pathways reviewed in this report may bring AML treatment into a new era.

Table 5: DNA Methyltransferase inhibitors in clinical trials

\begin{tabular}{|c|c|c|c|c|c|c|c|}
\hline Study Agents & Other agents & Disease & Dosage & Clinical trails & No Pts & Response & Reference \\
\hline decitabine & $\mathrm{GO}$ & $\begin{array}{l}\text { Elderly, untreated } \\
\text { AML }\end{array}$ & $\begin{array}{l}20 \mathrm{mg} / \mathrm{m} 2 \mathrm{IV} \times 5 \mathrm{~d}, \mathrm{GO} \\
3 \mathrm{mg} / \mathrm{m}^{2} \mathrm{IV} \times 1 \mathrm{~d} 5\end{array}$ & Phase II & 33 & CR/CRp: 42\% & [39] \\
\hline decitabine & GO & $\begin{array}{l}\text { Relapsed and } \\
\text { refractory AML }\end{array}$ & $20 \mathrm{mg} / \mathrm{m} 2 \mathrm{IV} \times 5 \mathrm{~d}$ & retrospective & 79 & CR/CRp: 21\% & [40] \\
\hline Azacytidine & & $\begin{array}{l}\text { Elderly relapsed and } \\
\text { refractory AML }\end{array}$ & $75 \mathrm{mg} / \mathrm{m}^{2} / \mathrm{d}$ IV, d1-7 & retrospective & 184 & CR/CRi: $10 \%$ & [41] \\
\hline Azacytidine & $\begin{array}{l}\text { gemtuzumab } \\
\text { ozogamicin (GO) }\end{array}$ & high-risk AML & $75 \mathrm{mg} / \mathrm{m}^{2} / \mathrm{d}$ IV, d1-7 & retrospective & 56 & CR/CRi: $10 \%$ & {$[42]$} \\
\hline Azacytidine & Bortezomib & $\begin{array}{l}\text { Relapsed and } \\
\text { refractory AML }\end{array}$ & $75 \mathrm{mg} / \mathrm{m}^{2} / \mathrm{d}$ IV, d1-7 & Phase I & 23 & CR/CRi: $21 \%$ & [43] \\
\hline
\end{tabular}

Abbreviations: GO: gemtuzumab ozogamycin; CR: complete remission; CRi: CR with incomplete count recovery; CRp: CR without platelet recovery; MTD: maximal tolerated dose; 
Table 6: Novel agents in clinical trials

\begin{tabular}{|c|c|c|c|c|c|c|c|}
\hline Study Agents & Other agents & Disease & Dosage & Clinical trails & No Pts & Response & Reference \\
\hline $\begin{array}{l}\text { CPX-351 } \\
\text { (liposomal cytarabine: } \\
\text { daunorubicin at 5:1) }\end{array}$ & & $\begin{array}{l}\text { Elderly } \\
\text { untreated AML }\end{array}$ & $100 \mathrm{u} / \mathrm{m}^{2} \mathrm{D} 1,3,5$ & Phase llb & 45 & $\begin{array}{l}\text { acceptable } \\
\text { toxicity and } \\
\text { comparable to } \\
\text { standard } \\
\text { regimen }\end{array}$ & [9] \\
\hline $\begin{array}{l}\text { Voreloxin (anticancer } \\
\text { quinolone derivative) }\end{array}$ & & $\begin{array}{l}\text { Elderly } \\
\text { untreated AML }\end{array}$ & $72 \mathrm{mg} / \mathrm{m}^{2} \mathrm{qw} \times 3$ & Phase II & 105 & CR/CRp: $47 \%$ & {$[45]$} \\
\hline Amonafide (AS1413) & Cytarabine & Secondary AML & $600 \mathrm{mg} / \mathrm{m}^{2} / \mathrm{d}$ IV d1-5 & Phase II & 88 & CR/CRi: $42 \%$ & {$[46]$} \\
\hline behenoylara- $\mathrm{C}$ & $\begin{array}{l}\text { Idarubicin } \\
\text { Etoposide }\end{array}$ & untreated AML & $\begin{array}{l}300-350 \mathrm{mg} / \mathrm{m}^{2} \\
\times 10 \mathrm{~d}\end{array}$ & Phase II & 165 & CR: $87 \%$ & {$[47]$} \\
\hline Lenalidomide & $\begin{array}{l}\text { Cytarabine, } \\
\text { Daunorubicin }\end{array}$ & $5 q-A M L / M D S$ & $10 \mathrm{mg} / \mathrm{d}$ po d1-21 & Phase I/II & 18 & CR/CRi: $47 \%$ & {$[50]$} \\
\hline Ribavirin & Cytarabine & AML & & & 13 & CR:7\% & {$[51]$} \\
\hline ARRY-520 & idarubicin & refractory AML & $0.8-5.6 \mathrm{mg} / \mathrm{m} 2 \mathrm{IV}$ & Phase I & 33 & MTD: $4.5 \mathrm{mg} / \mathrm{m} 2$ & {$[52]$} \\
\hline AZD1152 & & relapsed AML & $50 \mathrm{mg}-1600 \mathrm{mg}$ & Phase I/II & 64 & MTD: $1200 \mathrm{mg}$ & {$[53]$} \\
\hline AZD6244 & & AML & $100 \mathrm{mg}$ po bid & Phase II & 47 & $\begin{array}{l}\text { Feasible } \\
\text { treatment }\end{array}$ & {$[56]$} \\
\hline Terameprocol & & $\begin{array}{l}\text { relapsed and } \\
\text { refractory AML }\end{array}$ & $1000-2200 \mathrm{mg}$ iv, $3 / \mathrm{w}, \times 2-3 \mathrm{w}$ & Phase I/II & 16 & MTD: $1500 \mathrm{mg}$ & {$[57]$} \\
\hline
\end{tabular}

Abbreviations: CR: complete remission; CRi: CR with incomplete count recovery; CRp: CR without platelet recovery; MTD: maximal tolerated dose;

Competing interests

The authors declare that they have no competing interests.

\section{Authors' contributions}

$X Z$ and $D L$ are involved in concept design. All authors participated in data collection, drafting and critically revising the manuscript.

\section{Acknowledgements}

This work was partly supported by New York Medical College Blood Diseases Fund.

\section{Author Details}

1Department of Hematology, First Hospital of Quanzhou Affiliated to Fujian Medical University, Quanzhou, 362000, China and 2Division of Hematology and Oncology, New York Medical College, Valhalla, NY 10595, USA

Received: 9 March 2010 Accepted: 23 April 2010

Published: 23 April 2010

\section{References}

1. Dillman RO, Davis RB, Green MR, Weiss RB, Gottlieb AJ, Caplan S, et al:: A comparative study of two different doses of cytarabine for acute myeloid leukemia: a phase III trial of Cancer and Leukemia Group B. Blood 1991, 78:2520-2526.

2. Larson RA: Is modulation of multidrug resistance a viable strategy for acute myeloid leukemia? Leukemia 2003, 17:488-491.

3. Kolitz JE, George SL, Dodge RK, Hurd DD, Powell BL, Allen SL, et al:: Dose Escalation Studies of Cytarabine, Daunorubicin, and Etoposide With and Without Multidrug Resistance Modulation With PSC-833 in Untreated Adults With Acute Myeloid Leukemia Younger Than 60 Years: Final Induction Results of Cancer and Leukemia Group B Study 9621. J Clin Oncol 2004, 22:4290-4301.

4. Pautas C, Merabet F, Thomas X, Raffoux E, Gardin C, Corm S, et al:: Randomized Study of Intensified Anthracycline Doses for Induction and Recombinant Interleukin-2 for Maintenance in Patients With Acute Myeloid Leukemia Age 50 to 70 Years: Results of the ALFA-9801 Study. J Clin Oncol 2010, 28:808-814.
5. Fernandez HF, Sun Z, Yao X, Litzow MR, Luger SM, Paietta EM, et al:: Anthracycline dose intensification in acute myeloid leukemia. N Engl J Med 2009, 361:1249-1259.

6. Lowenberg B, Ossenkoppele GJ, van Putten W, Schouten HC, Graux C, Ferrant $A$, et al:: High-dose daunorubicin in older patients with acute myeloid leukemia. N Engl J Med 2009, 361:1235-1248.

7. Rowe JM: Optimal induction and post-remission therapy for AML in first remission. Hematology 2009, 2009:396-405.

8. Feldman EJ, Lancet J, Kolitz JE, Ritchie E, List AF, Asatiani E, et al:: Phase I Study of a Liposomal Carrier (CPX-351) Containing a Synergistic, Fixed Molar Ratio of Cytarabine (Ara-C) and Daunorubicin (DNR) in Advanced Leukemias. Blood 2008, 112:. abstract no. 2984.

9. Lancet JE, Feldman E J, Kolitz J E, Tallman M S, Hogge D E, Komrokji R S, et al.: Phase IIb Randomized Study of CPX-351 Vs. Conventional Cytarabine + Daunorubicin in Newly Diagnosed AML Patients Aged 6075: Safety Report. Blood 2009, 114:Abstract No1033.

10. Kell WJ, Burnett AK, Chopra R, Yin JAL, Clark RE, Rohatiner A, et al:: A feasibility study of simultaneous administration of gemtuzumab ozogamicin with intensive chemotherapy in induction and consolidation in younger patients with acute myeloid leukemia. Blood 2003, 102:4277-4283.

11. Burnett AK, Kell W, Goldstone AH: The Addition of Gemtuzumab Ozogamicin to Induction Chemotherapy for AML Improves Disease Free Survival without Extra Toxicity: Preliminary Analysis of 1115 Patients in the MRC AML15 Trial. Blood 2006, 108:. Abstract No. 13

12. Borthakur G, Faderl S, Verstovsek S, Jones D, Gandhi V, Estrov Z, et al: Clinical and Molecular Response in Core Binding Factor Acute Myelogenous Leukemia with Fludarabine, Cytarabine, G-CSF and Gemtuzumab Ozogamicin. Blood 2009, 114:. Abstract No.2056.

13. Paolini S, Parisi S, Candoni A, Piccaluga PP, Gottardi M, Laterza C, et al:: Four Drugs Induction Therapy (fludarabine, cytarabine, idarubicin and gemtuzumab ozogamycin) for the Treatment of Elderly Acute Myeloid Leukemia Patients. Blood 2009, 114:. Abstract No.1027.

14. Larson S, Campbell N, Huo D, Artz A, Zhang Y, Gajria D, et al:: High Dose Cytarabine (HiDAC) and Mitoxantrone (MITO) Is An Effective Induction Therapy for High-Risk Acute Myeloid Leukemia. Blood 2009, 114: Abstract No.1048.

15. Miyawaki S, Hatsumi N, Yamauchi T: Phase 2 Study of FLAGM (Fludarabine+High-Dose Ara-C +G-CSF+Mitoxantrone) for Relapsed or 
Refractory Acute Myeloid Leukemia (AML): A Report From the Japan Adult Leukemia Study Group (JALSG). Blood 2009, 114:. Abstract No.1058.

16. Prébet T, Charbonnier A, Etienne A, D'Incan E, Fürst S, Blaise D: A Direct Comparison of High Dose Cytarabineto Combination of Gemtuzumab and High Dose Cytarabine for Acute Myeloid Leukemia Patients in First Relapse Confirmed the Benefit of Gemtuzumab Based Regimens. Blood 2009, 114:. Abstract No.2051.

17. Scappini B, Gianfaldoni G, Salvatore P, Susini M C, Izzo T, Mannelli F, et al.: High Dose Cytarabine, Clofarabine and Gemtuzumab Ozogamicin (CLAC-MYL) in Relapsed or Refractory AML Patients. Blood 2009, 114: Abstract No.1060.

18. Erba HP, Faderl S, Claxton D F, Arellano M, Lyons R M, Kovacsovics T J, et al.: Single-Agent Clofarabine Produces Durable Remissions in Patients with Acute Myelogenous Leukemia (AML) Who Are $=70$, Have Intermediate or Unfavorable Cytogenetics, Antecedent Hematological Disorders (AHD), or 2 or More Unfavorable Prognostic Factors. Blood 2009, 114:. Abstract No.2083.

19. Becker PS, Estey E, Petersdorf S, Storer B E, Appelbaum F R: G-CSF Priming, Clofarabine and High Dose Cytarabine (GCLAC) for Relapsed or Refractory Acute Myeloid Leukemia (AML). Blood 2009, 114:. Abstract No.2068.

20. Foster MC, Amin C, Voorhees P M, Van Deventer H W, Richards K L, Anastasia I, et al:: A Phase I, Dose Escalation Study of Clofarabine in Combination with Fractionated Gemtuzumab Ozogamicin in Relapsed and Refractory Acute Myeloid Leukemia (AML). Blood 2009, 114:. Abstract No.2048.

21. Parikh SA, Hagop K, Garcia-Manero G, Jabbour E, Kadia T, Ravandi F, et al. Clofarabine Plus Low-Dose Cytarabine Induction Followed by Consolidation with Clofarabine Plus Low-Dose Cytarabine Alternating with Decitabine as Frontline Therapy for Patients (pts) with Acute Myeloid Leukemia (AML) $=60$ Years (yrs). Blood 2009, 114:. Abstract No.2058.

22. Kantarjian HM, Garcia-Manero G, Luger S, Venugopal P, Maness L J, Wetzler M, et al:: A Randomized Phase 2 Study of Sapacitabine, An Oral Nucleoside Analogue, in Elderly Patients with AML Previously Untreated or in First Relapse. Blood 2009, 114:. Abstract No.1061

23. O'Brien S, Rizzieri D A, Vey N, Ravandi F, Krug U O, Sekeres M A, et al:: APhase II Multicentre Study with Elacytarabine as Second Salvage Therapyin Patients with AML. Blood 2009, 114: Abstract No.1042.

24. Gregory TK, Wald D, Chen Y, Vermaat JM, Xiong Y, Tse W: Molecular prognostic markers for adult acute myeloid leukemia with normal cytogenetics. J Hematol Oncol 2009, 2:23.

25. Metzelder S, Scholl S, Matthias K, Reiter A, Meyer R G, Heinicke T, et al: Compassionate Use of Sorafenib in Relapsed and Refractory Flt3-ITD Positive Acute Myeloid Leukemia. Blood 2009, 114:. Abstract No.2060.

26. Pemmaraju N, Kantarjian H M, Ravandi F, Garcia-Manero G, Gautam B, Parikh S A, et al:: FLT3 Inhibitor Therapy for Patients with Myelodysplastic Syndromes (MDS) and Acute Myeloid Leukemia (AML): Impact On Survival According to FLT3 Status. Blood 2009, 114: Abstract No. 1026.

27. Schroeder T, Saure C, Bruns I, Zohren F, Czibere A G, Safaian N N, et al:: Clinical Efficacy of Sorafenib in Patients with Acute Myeloid Leukemia (AML) and Activating FLT3-Mutations. Blood 2009, 114:. Abstract No.2057.

28. Al-Kali A, Jones D, Cortes J, Faderl S, Xue A, Garcia-Manero G, et al: Patterns of Molecular Response to and Relapse After Combination of Sorafenib, Idarubicin, and Cytarabine in Patients with Newly Diagnosed FLT3-Mutant Acute Myeloid Leukemia (AML). Blood 2009, 114: Abstract No.2079.

29. Baum K, Ren R: Effect of Ras Inhibition in Hematopoiesis and BCR/ABL Leukemogenesis. Journal of Hematology \& Oncology 2008, 1:5.

30. Paolini S, Ottaviani E, Parisi S, Salmi F, Lama B, Curti A, et al:: RASGRP1/APTX Ratio Strongly Correlates with Clinical Response and Survival in AML Patients Treated with Tipifarnib-Bortezomib Combination. Blood 2009, 114: Abstract No.1028.

31. Feldman EJ, Ritchie E, Gergis U, Mayer S, Scandura J M, Christos P J, et al:: Evaluation of Alternative, "Low-intensity" Induction Regimens in Elderly Adults with Acute Myeloid Leukemia (AML). Blood 2009, 114: Abstract No.2066.

32. Cang $\mathrm{S}, \mathrm{Ma}$ Y, Liu D: New clinical developments in histone deacetylase inhibitors for epigenetic therapy of cancer. J Hematol Oncol 2009, 2:22
33. Siegel D, Hussein M, Belani C, Robert F, Galanis E, Richon VM, et al:: Vorinostat in solid and hematologic malignancies. J Hematol Oncol 2009, 2:31

34. Tan J, Cang S, Ma Y, Petrillo RL, Liu D: Novel histone deacetylase inhibitors in clinical trials as anti-cancer agents. J Hematol Oncol 2010 3:5.

35. Sanchez-Gonzalez B, Yang H, Bueso-Ramos C, Hoshino K, QuintasCardama A, Richon VM, et al: Antileukemia activity of the combination of an anthracycline with a histone deacetylase inhibitor 2. Blood 2006, 108:1174-1182

36. Shiozawa K, Nakanishi T, Tan M, Fang HB, Wang WC, Edelman MJ, et al: Preclinical studies of vorinostat (suberoylanilide hydroxamic acid) combined with cytosine arabinoside and etoposide for treatment of acute leukemias 1. Clin Cancer Res 2009, 15:1698-1707.

37. Garcia-Manero G, Tambaro F P, Bekele N B, Jabbour E, Ravandi F, Yang H, et al:: Phase II Study of Vorinostat in Combination with Idarubicin (Ida) and Cytarabine (ara-C) as Front Line Therapy in Acute Myelogenous Leukemia (AML) or Higher Risk Myelodysplastic Syndrome (MDS). Blood 2009, 114: Abstract No.1055.

38. Kirschbaum M, Ivana G, Goldberg S L, Kujawski L, Atallah E, Marks P, et al: Vorinostat in Combination with Decitabine for the Treatment of Relapsed or Newly Diagnosed Acute Myelogenous Leukemia (AML) or Myelodysplastic Syndrome (MDS): A Phase I, Dose-Escalation Study. Blood 2009, 114:. Abstract No.2089.

39. Borthakur G, Garcia-Manero G, Estrov Z, Konopleva M, Burger J A, Thomas De A, et al:: Phase 2 Study of Decitabine and Gemtuzumab Ozogamicin in Acute Myelogenous Leukemia and High-Risk Myelodysplastic Syndrome-Outcome in Previously Untreated Patients. Blood 2009, 114: Abstract No.1053.

40. Ritchie EK, Arnason J, Feldman E J, Gergis U S, Mayer S A, Ippoliti C, et al: Decitabine-Based Salvage Therapy in Adults with Acute Myeloid Leukemia. Blood 2009, 114:. Abstract No.2063.

41. Itzykson R, Thepo S, Reche C, Delaunay J, Quesnel B: Azacytidine in Refractory or Relapsed AML After Intensive Chemotherapy (IC): Results of the French ATU Program. Blood 2009, 114:. Abstract No.1054.

42. Michaelis LC, Shafer D, Barton K, Rodriguez T, Smith S, Stiff P, et al.: Azacitadine and Low-Dose Gemtuzumab Ozogamicin for the Treatment of Poor-Risk Acute Myeloid Leukemia (AML) and Myelodysplastic Syndromes (MDS), Including Relapsed, Refractory Disease. Blood 2009, 114:. Abstract No.1034.

43. Blum W, Klisovic R B, Walker A, Garzon R, Liu S, Schaaf L J, et al: Epigenetic Targeting Via Transcriptional Inhibition of DNA Methyltransferase: a Phase I Study of Bortezomib in Combination with 5-Azacytidine in Adults with Relapsed or Refractory Acute Myeloid Leukemia (AML). Blood 2009, 114:. Abstract No.2065.

44. Silverman LR, Verma A, Odchimar-Reissig R, LeBlanc A, Najfeld V, Gabrilove J, et al: A Phase I Trial of the Epigenetic Modulators Vorinostat, in Combination with Azacitidine (azaC) in Patients with the Myelodysplastic Syndrome (MDS) and Acute Myeloid Leukemia (AML): A Study of the New York Cancer Consortium. ASH Annual Meeting Abstracts 2008, 112:3656.

45. Ravandi F, Kantarjian H M, Cripe LD, Maris M, Cooper M, Dakhil S R, et al:: A Phase 2 Dose Regimen Optimization Study of Three Schedules of Voreloxin as Single Agent Therapy for Elderly Patients with Newly Diagnosed Acute Myeloid Leukemia. Blood 2009, 114:. Abstract No.1037.

46. Erba HP, O'Donnell M, Allen S L, Baer M R, Powell B L, Stone R M, et al:: Amonafide L-Malate (AS1413) in Combination with Cytarabine Is Equally Effective in Older and Younger Patients with Secondary Acute Myeloid Leukemia (AML); Final Data From a Phase II Study. Blood 2009, 114: Abstract No.1047.

47. Kyo T, Kimura A, Kyo K, Yoshida N, Asaoku H, Iwato K, et al.: High Remission Rates and Long-Term Survival in a High Percentage of Patients Achieved by Intensive Chemotherapy for AML and Further Improvement of Supportive Care. Blood 2009, 114:. Abstract No.1052.

48. Raza A, Galili N, Callander N, Ochoa L, Piro L, Emanuel P, et al.: Phase 1-2a multicenter dose-escalation study of ezatiostat hydrochloride liposomes for injection (Telintra(R), TLK199), a novel glutathione analog prodrug in patients with myelodysplastic syndrome. J Hematol Oncol 2009, 2:20. 
49. Kotla V, Goel S, Nischal S, Heuck C, Vivek K, Das B, et al: Mechanism of action of lenalidomide in hematological malignancies. $J$ Hematol Oncol 2009, 2:36.

50. Ades L, Stamatoullas A, Raffoux E, Prebet T, Lenain P, Guieze R, et al:: Lenalidomide (LEN) Combined to Intensive Chemotherapy (IC) in AML and Higher Risk MDS with Del 5q. Interim Results of a Phase I/II Study. Blood 2009, 114:. Abstract No.1049.

51. Assouline SE, Cocolakis E, Rousseau C, Culjkovic B, Beslu N, Amri A, et al:: Targeting the Oncogene elF4E with Ribavirin: A Novel Therapeutic Avenue in Acute Myeloid Leukemia. Blood 2009, 114:. Abstract No.2085.

52. Garcia-Manero G, Khoury J H, Borthakur G, Ravandi F, Kadia T, Estrov Z, et al:: A Phase 1 Dose-Escalation Study of the Novel KSP Inhibitor ARRY520 in Advanced Leukemias. Blood 2009, 114:. Abstract No.2047.

53. Lowenberg B, Rousselot P, Martinelli G, Goudie A, Stockman P, Kantarjian $\mathrm{H}$ : Phase I/II Study to Assess the Safety and Efficacy of the Aurora B Kinase Inhibitor, AZD in Patients with Advanced Acute Myeloid Leukemia. Blood 1152, 114: Abstract No.2080.

54. Fremin C, Meloche S: From basic research to clinical development of MEK1/2 inhibitors for cancer therapy. Journal of Hematology \& Oncology 2010, 3:8.

55. Tai YT, Kim K, Li XF, Fulciniti M, Song W, Nahar S, et al.: Targeting MEK1/2 Signaling Cascade by AS70 a Novel Selective MEK1/2 Inhibitor, Induces Pleiotropic Anti-Myeloma Activity in Vitro and In Vivo. ASH Annual Meeting Abstracts 2009, 114:3848.

56. Odenike O, Curran E, lyengar N, Popplewell L, Kirschbaum M, Erba H P, et al: Phase II Study of the Oral MEK Inhibitor AZD6244 in Advanced Acute Myeloid Leukemia (AML). Blood 2009, 114:. Abstract No.2081.

57. Tibes R, McDonagh KT, Lekakis L, Frazer N, Mohrland S, Dawn B, et al.: Phase I Study of the Novel Survivin and cdc2/CDK1 Inhibitor Terameprocol in Patients with Advanced Leukemias. Blood 2009, 114: Abstract No.1039.

doi: 10.1186/1756-8722-3-17

Cite this article as: Zhu et al., Novel agents and regimens for acute myeloid leukemia: 2009 ASH annual meeting highlights Journal of Hematology \& Oncology 2010, 3:17

\section{Submit your next manuscript to BioMed Central} and take full advantage of:

- Convenient online submission

- Thorough peer review

- No space constraints or color figure charges

- Immediate publication on acceptance

- Inclusion in PubMed, CAS, Scopus and Google Scholar

- Research which is freely available for redistribution

Submit your manuscript at www.biomedcentral.com/submit
Ciomed Central 